\title{
Roman Tomaszewski, $W$ Polsce i na obczyźnie. Zarys dziejów szkolnictwa woj- skowego 1939-1956, Wydawnictwo Adam Marszalek, Toruń 2006, ss. 279
}

Nakładem Wydawnictwa Adam Marszałek ukazała się w 2006 r. książka Romana Tomaszewskiego na temat szkolnictwa wojskowego w latach 1939-1956. Tematyka podjęta przez Autora jest bardzo interesująca, ponieważ stanowi element dziejów „branżowych”, w tym konkretnym przypadku wojska, które w najnowszej, dwudziestowiecznej historii Polski odegrało niebagatelną rolę. Zakres chronologiczny książki jest dodatkową atrakcją czytelniczo-poznawczą, ponieważ sugeruje, iż Autor rozprawy dążyć będzie przede wszystkim do badań porównawczych między epokami tak różnymi, jak: okres dwudziestolecia międzywojennego (do którego Autor w kontekście 1939 r. musi się odwołać), czas II wojny światowej i wreszcie historia PRL. Pozycja wojska, kwestie edukacji wojskowej i kondycji środowiska wojskowego w żadnej z nich nie były przecież takie same, nie były nawet podobne, trudno zatem mówić w tym przypadku o ciągłości tradycji w kształceniu, o kontynuacji tradycji i zachowań rytualnych, tak przecież istotnych w wojsku.

Wyzwaniem, jakie sobie również $\mathrm{R}$. Tomaszewski postawił, było także wyznaczenie, jak w każdej pracy historycznej, zakresu terytorialnego badanego zagadnienia, bo przecież teren II Rzeczypospolitej i aktywności Polaków w okresie ,wielkiej wojny”, głównie wojskowych właśnie, a także terytorium Polski Ludowej są diametralnie różnymi kategoriami geograficznymi.

Jak zatem autor przedstawił, wobec takich trudności metodologicznych, problematykę kształcenia wojskowego w okresie 1939-1956?

Przede wszystkim prezentowana książka jest świadectwem niekwestionowanej znajomości tematyki przez Autora. Taka ocena wynika głównie z dokładnego zestawienia bibliografii, z wzorowym podziałem wykorzystanego materiału na źródła archiwalne, źródła drukowane etc. Ich jakość i ilość zasługują na uznanie, aczkolwiek czułam niedosyt wykorzystania materiałów pozostających poza granicami kraju, szczególnie w odniesieniu do okresu II wojny światowej, kiedy Polacy często zdobywali potrzebną wiedzę wojskową, zwykle w sposób nieformalny, poza ojczyzną. Ale zarzut ten także dotyczyć może okresu PRL, gdy polskie (?) kadry wojskowe pozostawały pod wpływem i w zależności od Związku Radzieckiego. Być może jednak takie źródła nie istnieją, bądź nie są dostępne...

Zawartość tekstowa pokazuje także, że Autora ciekawią przede wszystkim, wbrew tytułowi, czasy peerelowskie. R. Tomaszewskiego interesuje fakt „ekstremalnego przewartościowania", jakie nastąpiło w ,antyrosyjsko, antyradziecko i antykomunistycznie nastawionym społeczeństwie" w latach 1939-1949. Nie do końca można zgodzić się z tak postawionym problemem, gdyż cała najnowsza historia Polski pokazuje jasno, że w polskim narodzie nigdy nie było przyzwolenia na komunizm i radziecką dominację. Polaków po prostu w wielu zasadniczych kwestiach nikt o zdanie nie pytał. Niektóre grupy społeczne, czy zawodowe dały się jednak „uwieść” systemowi i do nich właśnie należy zaliczyć wojsko. $Z$ mojej natomiast strony byłoby nieuczciwe, gdybym stawiała znak równości między środowiskiem wojskowych z okresu sprzed II wojny światowej 
a czasami „ludowymi”. Te dwie różne epoki oznaczają także dwa różne rozumienia elit wojskowych i pojęcia „służba dla państwa”. I te rozbieżności widoczne były w procesie kształcenia wojskowego. R. Tomaszewski dobrze i wystarczająco te różnice przedstawił.

Niewątpliwą jednak zaletą książki jest to, że Autor wszelkie kwestie kształcenia wojskowego postrzegał i przedstawił na tle ogólnych wydarzeń polityczno-społecznych, częściowo właśnie nimi tłumacząc pewne determinanty zachowań. Szczególnie jest to przydatne w rozdziale dotyczącym kształcenia wojskowego w latach 1944-1946. Te treści wypełniają część pierwszą pracy i pokazują, jak Wojsko Polskie w owym czasie stanowiło przedmiot sporu politycznego. Rozdział drugi natomiast poświęcony jest szkolnictwu w okresie demobilizacji i tworzenia struktur pokojowych Wojska Polskiego w latach 1946-1948. Ostatnia część z kolei zatytułowana została: „Próba zaprzeczenia tradycji - szkolnictwo Wojska Polskiego a stalinizm (1949-1955)". W moim przekonaniu jest to jednocześnie „najmocniejszy” element pracy, bo pokazuje wiele „białych plam” w najnowszej historii, odbrązawia wiele mitów.

Konstrukcja treści jest logiczna, aczkolwiek niekonsekwentnie Autor zastosował ramy czasowe: z tytułu wynika, iż rozważania w całej książce dotyczą okresu 1939-1956, natomiast w rozdziałach krańcowymi datami są lata 1944-1955.

Przy lekturze książki zwróciłam także uwagę na niezwykłą rzetelność edytorską Autora. Jego praca bowiem jest niezwykle starannie wyposażona w przypisy, wykaz skrótów, tabele, rysunki, zdjęcia. Zabrakło jedynie indeksu osób, bardzo przydatnego w tego typu opracowaniach. Książka jest przygotowana nie tylko dla czytelnika polskiego, ale także anglo-, francusko-, niemiecko- i rosyjskojęzycznego (wprowadzenie, spis treści i uwagi końcowe w tych językach). Zaletą książki jest również język, jakim została napisana: jest poprawny gramatycznie, „żywy", ułatwia lekturę wcale niełatwych (fachowych) problemów.

Praca R. Tomaszewskiego stanowi zatem bardzo wartościową pozycję nie tylko w zakresie historii politycznej, wojskowości, ale także historii wychowania, gdzie tak wielokierunkowe badania zasługują na uwagę.

Edyta Gtowacka-Sobiech

\section{W slużbie historii nauki, kultury $i$ edukacji. Księga pamiqutkowa dedykowana prof. Lechowi Mokrzeckiemu z okazji jubileuszu pięćdziesięciolecia pracy za- wodowej, pod red. R. Grzybowskiego i T. Maliszewskiego, Wydawnictwo Uniwersytetu Gdańskiego, Gdańsk 2006, ss. 488}

Publikacje pamiątkowe są wydawnictwami nietypowymi - podobnie zresztą jak i osoby, którym są dedykowane. Tak właśnie jest i w tym konkretnym przypadku, kiedy mowa jest o pracy $W$ stużbie historii nauki, kultury $i$ edukacji. Księga pamiątkowa dedykowana prof. Lechowi Mokrzeckiemu z okazji pięćdziesięciolecia pracy zawodowej, która ukazała się w 2006 r., nakładem Wydawnictwa Uniwersytetu Gdańskiego. Na czym ta podwójna wyjątkowość, publikacji i Jubilata, polega? 